\title{
Curriculum Theorising in an Economics Education Programme
}

\author{
S.M. Maistry \\ ORCID iD: https://orcid.org/0000-0001-9623-0078
}

\section{Abstract}

The Covid-19 pandemic is having a serious effect on all aspects of society. It presents with novel challenges for higher education curriculum theorising since it brings into view the need to re-orient thinking in this field. Higher education curriculum theorising in economic education, in particular, has been strongly connected historically to the nature of Economics as a discipline, as well as its fundamental tenets of economic efficiency, utility maximisation, trade-offs, and quantifiable justification for economic decision making. The discipline of Economics has its genesis in neoclassical Economics and addresses two key issues: the need to solve the economic problem of scarcity; and the maximising of human need satisfaction. In this paper, I draw on Decolonial Critique and Posthumanism to explore through self-study research, how canonical thought and principles pertinent to Economics might be disrupted in a teacher education programme for pre-service teachers of Economics. I trouble the centrality of human need satisfaction as the paramount objective of the field with a view to reflecting on the application of a disruptive curriculum to contest traditional disciplinary economic knowledge. I contemplate a decolonial approach to curriculum theorising at the borders of the colonial matrix of power, an approach that problematizes neoclassical Economics and neoliberalism's preoccupation with narcissistic human needs prioritisation in favour of philosophical posthuman and decolonial perspectives that reposition the human subject in a critical, equivalent, reciprocal relation to the non-human in the (post)Anthropocene. In this paper, I offer specific insights for alternative curriculum theorising in Economics education and curriculum theorising in general.

Keywords: curriculum, Economics, theorising, border thinking 


\section{Introduction}

The year 2020 marks a watershed moment in the historical trajectory of humankind, the dominant being on planet Earth, a year (which is barely halfcomplete at the time of writing this article) in which the outbreak of the COVID-19 pandemic is presenting as unprecedented crisis. That the repercussions have been catastrophic and that it has created chaos and panic is without contention. The pandemic has certainly precipitated a dramatic change in human behaviour on a global scale. How then might curriculum theorising in the context of a societal transformation agenda now be envisaged? Where might curriculum theorists draw inspiration to address curriculum transformation that the current milieu presents with poverty and socio-economic inequality now firmly under the spotlight?

Poverty and inequality have been pervasive features of modern society for centuries, yet intervention strategies to alleviate the plight of the poor have had somewhat limited effect (Gray \& Maharaj 2016; Pogge 2010). The pandemic, as devastating as it is, has had what we might call potentially positive spinoffs for the indigent. The eyes of the world have been forced to focus on this very public affliction and the publics that are most vulnerable. This accentuated focus has become a powerful driver of social intervention programmes across the world. In South Africa, political denial, evasion, and avoidance of the prevalence of widespread socio-economic inequality have become increasingly difficult issues for the political elite to negotiate. The absence of running water and ablution facilities in more than 3,000 South African schools is a social injustice beyond comprehension. In essence then, the current pandemic has drawn sharp attention to how socio-economic inequality manifests and plays itself out during a crisis, especially as it relates to the provisioning of health and education. How then might curriculum theorists respond and from where might they seek theoretical inspiration?

In this paper, I present an approach to curriculum theorising in a teacher education curriculum and pedagogy course on offer in the School of Education at the University of KwaZulu-Natal. This particular preservice teacher education course entitled Economics Teaching is a teaching specialisation offered to the Postgraduate Certificate in Education (PGCE) students, a so-called capping programme for prospective Bachelor's graduates who wish to pursue a career in teaching. Prospective teachers of Economics enter the programme with Economics as a major subject in their undergraduate 


\section{S.M. Maistry}

degree. These candidates would have been exposed to a typical university Economics curriculum comprised of both basic and advanced Macroeconomics and Microeconomics in their initial exposure to the subject, as well as sub-disciplinary specialisation knowledge from among Monetary Economics, Labour Economics, and/or Public Sector Economics. Of significance is that neoclassical Economics remains the bedrock from which the body of Economic knowledge has developed and continues to grow (Petkus et al. 2014). The overview of fifty years of Economic education scholarship in The Journal of Economic Education since its inception in 1969 (Hoyt \& McGoldrick 2019) is a clear reflection of the focus Economics education researchers have taken on teaching, learning, and assessment in Economics. It reflects the taken-for-granted nature of the fundamental disciplinary knowledge and principles of Economics that Economics education researchers and pedagogues both at school and university level have adopted. The discipline (and disciplinary knowledge) remains sacrosanct. The scholarly endeavour has been entirely focussed on how to better teach and assess the canon. While university Economics students have expressed some dissatisfaction with the discipline's ability to explain financial crises, Shiller (2010) reminds us that this discontent has been mild and that the discipline has in fact seen an increase in subscription by students keen to lap up the subject's knowledge. Raghuram (2010) alerts us to the fact that even the sub-field of development Economics and standard macroeconomic models have not been successful in resolving issues related to the plight of developing nations during times of economic crises. The Economics textbook publishing industry has paid cursory attention to amending the content in undergraduate textbooks especially as it relates to responding to the failings of world capitalism and the crash of financial markets (Madsen 2013). It is necessary to rethink what is taught to undergraduate Economics students especially in terms of the failure of (Economics) textbook knowledge to explain economic crises (Friedman 2010). Neoclassical Economics and its associated so-called fundamental principles continue to remain central to Economics programmes around the world, both in schools and post-school academic offerings. Profit-making, economic growth, and the optimum exploitation of natural resources is a distinct feature of the Anthropocene, with humankind centrally positioned as main benefactor and arbiter of the relationship between people and nature. It has become clear that in the current geological age, the dominance of humankind in its quest for human needs satisfaction through exploitative 
human economic activity has presented the planet with potentially cataclysmic outcomes should this human economic activity continue unchecked. This is the problem that I attempt to address in this paper by mounting a humble challenge to the western-Eurocentric Economics curriculum, based on neoclassical Economics principles, through a teacher-training course for teachers of Economics.

In speaking to the brief of this special issue, namely, 'to illuminate the thinking and theorising that informs (the) curriculum transformation', I reflect on the theoretical strands that influence the teaching and learning dynamics at play as I engage pre-service teachers of Economics in the contemplation of an alternative to the teaching of the traditional neoclassical Economics canon. I consider how a different conjuring might produce an alternative set of futurities to what currently manifests. To achieve this new imaginary, I appropriate from critical transformative theories that have, as significant intent, the need to interrogate knowledge frameworks (like neoclassical Economics) with a view to exposing how they actively contribute to socio-economic inequality. I draw on key tenets and conceptualisations from Decolonial Critique and Posthumanism to argue for the curriculum transformation moves I present to my pre-service students.

While posthumanism and decolonial critique might be considered disparate with regard to their ontological and epistemological premises, for me they share a common intent which, following Zembylas (2018), is to transcend the normative conception of the human so as to move beyond and through this normative conception.

\section{A Brief Methodological Note}

To address the focus of this special issue, I draw on data from my ongoing project of researching my practice as teacher educator and postgraduate research supervisor. While the concept of lifelong learner has become something of a cliché in South Africa, I fully embrace the notion of contributing to the scholarship of teaching and, importantly, of sustaining a process of continuous personal renewal as Feldman (2009) advocates by centring my (fallible) self as continual object of study. Self-study as an emerging methodological field has significant appeal and, in the past two decades, self-study research has gained significant traction in the teacher education arena. It is a field of inquiry that firmly recognises the 


\section{S.M. Maistry}

embeddedness of the teacher in researching her or his own practice, a situatedness that demands candid and careful introspection and reflection on one's practice as teacher (Samaras 2011).

Self-study emphasises the implicated nature of the teacher in the teaching and learning enterprise. The teacher as human subject with a particular history and biography becomes crucial in troubling, deconstructing, and reconstructing the self (Samaras \& Freese 2009). As teacher, my history and biography as a descendent of Indian labourers imported into South Africa in 1860 means that I am certainly not indigenous to the continent although I am South African. As a university academic, I occupy middle-class status. While I hail from humble beginnings, I currently live in the suburbs, and am a heterosexual male firmly embedded in a colonial society and socialised into a colonial lifestyle. These are crucial issues since they are implicated in how I embrace the societal and curriculum transformation project. Self-study, while supporting a range of data generation methods including memory work, autobiography, and narrative life history, does not subscribe to positivist notions of validity and reliability but, instead, invokes qualitative constructs such as credibility and trustworthiness (Craig 2009). Some scholars in this emerging field encourage self-study research to be systematic (Samaras 2011). Of course, critical reflection on one's practice seldom happens in any uniform or linear fashion. In fact, critical incidents are precisely that - incidents or occurrences that are unexpected or spontaneous and require of the self-study researcher an ongoing meta-awareness of stimuli or sources of inspiration that might enrich the project of teaching. As a self-study researcher, much of what I think of as my data presents itself when I least expect it to. It might entail the taking of mental notes or scribbling on notepads or pieces of paper (in meetings, in my classroom, at a conference, while waiting to board a plane and so forth). Giving effect to a particular pedagogic action might entail meditating on an issue or a phenomenon and harnessing the various data pieces to create the narrative that I wish to compose. Student personal narratives as they relate to their experiences of race, class, or gender in the economic world are powerful resources that offer rich context for making sense of economic concepts. As can be expected, this kind of research activity will have little currency in the traditional modernist scientific paradigm and post-positivist traditions that still hanker after the science standard, a 'cantankerous 'what constitutes truth' debate' (Craig 2009: 22), a discussion of which is beyond the scope of this paper. 
Arguably the strongest criticism levelled against self-study as an approach to research might be its degeneration into narcissistic, navel-gazing exercises in which the teacher researcher embarks on a project of romanticising her or his practice as opposed to adopting a disposition of humility and prudence in reflecting on achievements in that practice. In essence, then, my ongoing self-study (of my own practice as teacher educator) is a recognition that one never quite arrives, or that pre-specifying, in any rigid fashion, the precise co-ordinates of the outcomes of one's endeavours is not useful. The proverbial learning curve is undefined and likely to become pronounced and steep in times where precedence is absent, as in the current period of COVID-19 contagion. Of crucial importance is that the ultimate aim of self-study research is to improve one's teaching practices.

In the discussion that follows, I present an account of significant theoretical influences that have shaped and continue to shape curriculum theorising in the university courses I teach. I draw attention to the complexities and contradictions that present as I navigate the theoretical world in search of an elusive all-encompassing framework that might coherently speak to my critical project as teacher education activist. My somewhat late discovery of the seminal work of Gloria Anzaldúa, in particular, her Borderlands/La Frontera: The New Mestiza (1987) has, arguably, had the most profound influence on my thinking as a scholar and educational researcher. A discussion of the profundity of her insights is included later in the deliberations below of what has shaped my curriculum theorising and continues to do so.

\section{Tracing my Trajectory as Border Thinker}

In this section, I present an account of my personal journey in theorising curriculum and pedagogy by focussing on what shapes the teacher education programmes I teach for teachers of Economics and Business Sciences, a field, as mentioned earlier, that is saturated with neoclassical economic and neoliberal economic thinking. My presentation of a somewhat condensed, apparently linear account of just over two decades of practice in higher education runs the risk of essentialising what has been a tension-filled, fraught, and humbling experience as I engaged with demographically diverse students, the majority of whom were Black African first-generation university candidates. Among other objectives behind the design of pedagogy courses was the need to help my students read the world of Economics teaching as an 


\section{S.M. Maistry}

enterprise that entailed moving beyond simply acquiring pedagogical content knowledge as Shulman (2005) recommends, towards troubling the very foundations and principles on which the Economics they would teach to school learners, was based. The principle of pareto optimality for example is critiqued for its utopianism. Similarly, the notion of human beings as rational economic agents who always think at the margin (using marginal analysis) is interrogated for its relevance and practical applicability. Importantly, neoliberalism's preoccupation with economic growth and individual capital (wealth) accumulation at the expense of egalitarian redistributive economic modelling have been powerful in helping student teachers to (re)consider the kind of economic theory they might teach. It thus entails posing a challenge to the canonical capitalist model (see Picketty 2014), (especially its systematic marginalisation, othering, and asymmetrical gendered outcomes) that frames economic systems across the world.

The history of my experience of the world of curriculum theory can be traced back to my undergraduate study (my first teaching degree which I completed in 1987) at a university designated exclusively for Indian South Africans, the University of Durban-Westville (UDW), but administered by white South Africans during the apartheid era. The curriculum for this undergraduate teacher education programme certainly carried the pedagogic identity of the then ruling Nationalist party, namely that of Fundamental Pedagogics (FP) and Christian National Education (CNE) as Suransky-Dekker (1998) reminds us. Fundamental Pedagogics as a philosophy of education frames the teacher as authoritative adult tasked with the transmission of incontestable knowledge to passive learners (De Jager et al. 1985). My undergraduate and postgraduate Economics curriculum (at the University of South Africa) was based entirely on neoclassical economic foundations. As a schoolteacher (for nine years), my teaching philosophy and teaching methods were largely informed by my undergraduate training.

My first encounter with any alternative thinking about education and its methods and purposes came with my engagement with an Honours and subsequent Masters programme (completed in 1999) in Curriculum Studies at an English medium former whites-only university, the University of Natal (UN). During this time, I took up employment in the Faculty of Education at UD-W as a junior lecturer responsible for teaching methodology as it applied to Economic and Business Sciences school subjects. The postgraduate programme at UN was designed and taught by what might be regarded as the 
white liberal left, an intellectual block that actively challenged FP and CNE, the doctrine advanced by Afrikaner universities in South Africa (SuranskyDekker 1998). While the seminal work of Paulo Freire, Pedagogy of the Oppressed (1970) received some attention at UN, the theoretical influences were largely that of Anglo-American scholars. For me, Freire's disdain for banking education and his advocacy for problem-posing pedagogic praxis had distinct appeal.

The Faulty of Education at UD-W (where I worked) was at that time strongly influenced by the Dean, Jonathan Jansen, a critical scholar famous for his widely publicised denouncement of South Africa's move to an outcomesbased school curriculum (Jansen 1998) and his earlier critique of superficial alterations to the school curriculum in the immediate post-apartheid period (Jansen 1997). My exposure to key critical theorists influenced by the Frankfurt School and the work of Henri Giroux (2004) and Peter McLaren's (2005) advocacy for pedagogy to be seen and practised as a political project of disrupting cultural, political, economic, scientific, military, and technological hegemony, provided a powerful alternative frame in which to understand curriculum. This was complemented by Harvey's (2007; 2010) analysis of neoliberalism and his critique of capitalism in its affording to the pedagogy programme I envisaged for my students a theoretical and conceptual language with which to contemplate the study of what and how to teach in the Economics and Business Science disciplines. These insights gave me a framework from which to contest the fundamental capitalist tenets of Economics as a discipline. The appropriation of critical pedagogy's notion of education (teaching) as a distinctly political act (of resistance) necessarily entails the contestation of relations of power implicated in received knowledge. In essence, conceiving of teaching as a political act provokes the question of the purpose of education and its articulation with economic growth.

The works of African American theorist, bell hooks (1994), Critical Race theorists like Yosso (2005) and Hannah Arendt (1973; 1998), continue to inspire the social justice direction of the pedagogy courses I have designed and taught in the last two decades. Key insights framed my attempts at a transgressive against-the-grain pedagogy that challenges constructions of race, gender, and class, in 'dark times' (Arendt 1998: 11). The use of testimonio, for example, as a pedagogic practice (Cervantes-Soon \& Carillo 2016), that contests Cartesian rationality and patriarchy allows for a pushing beyond dialogic teaching, inviting confession and reflection especially as it relates to 


\section{S.M. Maistry}

addressing sensitive issues of race, class, and gender prejudice. My attempts at theorising a different curriculum and pedagogy has been ongoing (even before the resurgence of higher education curriculum transformation initiatives triggered by the 'Fees must Fall' movement in 2015). This is reflected in my published journal articles, 'Transformation through the curriculum: Engaging a process of unlearning in Economics Education pedagogy' (Maistry 2011), 'Foregrounding a social justice agenda in Economic Education: Critical reflections of a teacher education pedagogue' (Maistry 2012a), and 'Using memory as a resource for pedagogy: Fashioning a "bridging pedagogical moment"' (Maistry 2012b). These pieces draw attention to how issues of social justice could be integrated into a pedagogy course for teachers of commercial subjects.

The works of contemporary philosopher Martha Nussbaum (2003; 2006; 2010) and economic theorist Amartya Sen $(2005,2009)$ have also been a source of inspiration for curriculum development and theorizing. Nussbaum's influential Not for Profit: Why the Democracy Needs the Social Sciences (2010) offers a compelling argument for questioning the neoliberalinformed instrumentalist purpose of education as being to serve the economy. The theoretical insights offered by these writers and those of other critical scholars like Bauman (2007), Bauman and Rovirosa-Madrazo (2010), and Pogge (2010) inspired a further attempt at theorizing the purpose of education in an article entitled 'Education for economic growth: A neoliberal fallacy!' (Maistry 2014). Theorising curriculum and pedagogy has become a project of resisting attempts to make classroom teaching simply a matter of technique and method, a necessary detraction from the neoliberal performative character of education.

Prospective teachers in the field of Economics and Business Sciences have to engage with the programmatic curriculum (the school textbook). In an attempt to unearth the subtext of school textbooks and theorise how textbook content is likely to shape the worldviews of its multiple users (including preservice and in-service teachers as well as learners), the work of Critical Discourse scholars has been particularly useful (see Fairclough 2003; Wodak 2005; Wodak \& Meyer 2009; Van Dijk 2006). Such scholars offer powerful conceptual and analytical tools for programmatic curriculum analysis. In the study of the portrayal of entrepreneurship knowledge presented in school textbooks for example, critical discourse analysis exposes particular embellishments, (un)witting foregrounding and backgrounding, as well as 
omissions and silences regarding certain knowledge pieces. This, together with the use of modality, nominalisation, and register help to reveal embedded neoliberal value systems presented as well as the distinctly gendered nature of textbook content. I developed scholarly pieces to advance this agenda. These include 'An analysis of economic modelling used in school economics textbooks' (Maistry 2015), 'Phantasmagoria: Communicating an illusion of entrepreneurship in South African school textbooks' (Maistry \& David 2017), and 'The school economics textbook as programmatic curriculum: An exploited conduit for neoliberal globalisation discourses' (Maistry \& David 2018). This curriculum and pedagogical theorisation is novel in the South African context.

The issue of gender prejudice is germane to the field of Economics and Business Sciences, an agenda that is foregrounded in the curriculum transformation project. The work of Judith Butler (1990: 2004) has particular salience since it offers a powerful framework for understanding how gender is performative and how stereotypical gender constructions manifest in the school and university curriculum. Butler's notion of dissolving socially constructed binary categorisations of man and woman and her advocacy for non-normative gender theory disturb the gendered monolith of traditional Economics education. Another article, 'The 'firstness' of male as automatic ordering: Gendered discourse in Southern African Business Studies school textbooks' (Pillay \& Maistry 2018) is an attempt at theorizing how curriculum is programmed (in textbooks) for consumption by learners. In a paper presented at the Southern African Educational Research Association 2019 conference (currently under review) entitled 'Disrupting oblivion and aligning with feminism: Critical autoethnographic reflections of a profeminist 'heterosexual male' teacher educator' I invoke the work of the profeminist writers, Burrell and Flood (2019). Poststructuralist thinkers like Foucault (1979; 2001) and Deleuze and Guattari (1987) although not curriculum/education philosophers, certainly offer sophisticated frameworks and concepts for understanding the society in which the educational enterprise is given effect, especially as it relates to the formation of the disciplined subject.

The Rhodes-must-Fall campaign which saw mainly Black South African students demanding a curriculum that was relevant to their indigenous context, triggered the institutionalisation of the higher education transformation project, resulting in a flurry of academic activity (conferences, 


\section{S.M. Maistry}

workshops, seminars) with a specific focus on the decolonisation of the curriculum. Dissatisfaction with western-Eurocentric theorisations and a sudden awareness of a vast body of decolonial scholarship marked what was the beginning of arguably the most traumatic and dissonant period of my life as a scholar and researcher. This was (and still is) a particularly unsettling period since, for the first time in my academic career, the western-European scholarship that I was bred on was under threat. Its relevance for understanding the complexities of the African context was in question! I came to the harsh realisation that the emancipatory (postmodern) approaches to curriculum and pedagogy that I was so wedded to remain haunted by the ghosts of Eurocentrism (Cervantes-Soon \& Carillo 2016), a critique that Grosfoguel (2007) describes as applying a Eurocentric frame to analyse non-European contexts, giving epistemic privilege to western thinkers (and continental philosophy).

As described earlier, my classes were comprised mainly of indigenous African students, many of whom were keen supporters of the decolonisation of the curriculum project. I realised that like my students, I lacked the theoretical or conceptual sophistication to adequately engage the decolonial project given my contemporary status and colonial socialisation. According to Quijano (2000) Western Eurocentrism, as hegemonic worldview, co-opts both witting and unwitting collaborators across racial and gender divides, naturalising its ideology, thus sustaining its generational transmission of a Euro-centric world view.

Up to that point, my engagement with decolonial scholarship was nonexistent. I subsequently attended several conferences and symposia on decolonisation and a decolonial summer school, in an attempt to immerse myself in this newfound theoretical oasis. The work of Quijano (2000), Mignolo (2009; 2002), Ramon Grosfoguel (2007; 2008; 2011; 2013) and Maldonado-Torres (2007) had particular appeal since they offer profound insights into Decolonial Critique, especially as it relates to understanding the modernity-coloniality-capitalist complex and a nuanced conception of the distinction between decolonisation and decoloniality as well as the workings of the colonial matrix of power.

Of profound significance to me is that much of this scholarship drew insights from the work of Frantz Fanon, African thinker and philosopher, who even with his having passed more than fifty years ago, continues to inspire contemporary decolonial thinkers. Having heard of Fanon, but not having 
engaged with his work created a further state of academic discomfort (and some degree of embarrassment) in my not having privileged the scholarship of arguably the foremost thinker to grace the African continent. The Wretched of the Earth (Fanon 1963) and Black Skins, White Masks (Fanon 1967) are resources that I attempt to make accessible to my students. Fanon's original works written at a particular time (and in a unique genre) often do not immediately resonate with students' current lived experiences and given their familiarity with contemporary texts. Concepts including modernity, epistemicide, linguiscide, femicide, racial hierarchisation, racialisation, the colonial matrix of power, coloniality, decoloniality, colonisation, and decolonisation are relatively scarce in usage in the curriculum field in South Africa. They do, however, offer a conceptual apparatus with which to think about societal transformation and curriculum transformation.

As mentioned above, South African higher education has witnessed an institutionally driven agenda based on decolonisation and transformation of the curriculum, an academic project for which the diverse demographic profile of South African academics, was not prepared. This is an issue I attempted to address in two articles, 'The higher education decolonisation project: Negotiating cognitive dissonance' (Maistry 2019a) and 'Fetishistic disavowal and elusive jouissance: The case of the South African higher education decolonization project' (Maistry 2019b) that attempt to theorise the experience of South African academics as they engage in the decolonization of the curriculum project. Inspiration for these works came from decolonial theory.

The dissonance I continue to experience, though, is with understanding how to navigate my contradictory identity (heterosexual, middle-class, Indian, South African, male) in embracing the transformation agenda. In the section that follows, I share my contemplation of how to manage this liminality.

\section{La Mestiza of Sorts ... Decoloniality and Border Thinking}

The context for the exposition below is that of the teacher education pedagogy curriculum for teachers of Economics and Business Sciences (a field unequivocally shaped by neoliberal economics and intimately connected to normative capitalism). Curriculum transformation then would entail an attempt at disrupting the knowledge (and ideology) embedded in the canon. In the section above, I presented an explanation of how postmodern theorisations (critical theory and critical pedagogy) were appropriated to challenge 


\section{S.M. Maistry}

neoliberal capitalism's threat to democracy and socio-economic equality. The key issue though was that postmodernism and Critical Pedagogy struggle to escape the shadow of modernist, western-Eurocentrism that lingers overhead (Cervantes-Soon \& Carillo 2016), a shadow that hangs over much of my scholarship on curriculum transformation to date.

My recent reading of the Anzaldúa's Borderlands/La Frontera: The New Mestiza (1987) mentioned above has assisted me in thinking about how I locate and identify myself as a non-indigenous, colonial, heterosexual male of Indian descent, and (self)-proclaimed academic activist with a social justice agenda. Through Anzaldúa's insights, in which she describes herself as '(c)radled in one culture, sandwiched between two cultures, straddling all three cultures and their value systems, la mestiza undergoes a struggle of flesh, a struggle of borders, an inner war' (1987: 78). I am starting to better understand myself as a border person raised in two cultures (Western Eurocentric Anglo and traditional Indian). Clearly, borders are not exclusively physical or geographical; there are psychological and sexual borderlands, borderlands that exist between races, classes, sexualities, and worldviews (Anzaldúa 1987) or 'metaphorical spaces of periphery and liminality' (Cervantes-Soon \& Carillo 2016: 282).

For me, straddling multiple borders has been uncomfortable. Having been schooled on a rich diet of modernity and colonial scholarship (which I ravenously devoured and continue to consume), and my recent encounter with decolonial scholarship has meant dealing with a self-loathing, experiencing a kind of intellectual trauma of searching for a scholarly home with which I can identify and that will give me comfort. Anzaldúa (1987) reminds me of the difficulty of maintaining one's integrity and identity as one occupies and dwells in the border, but there is equally an excitement, an exhilaration at the thought that one has the potential and capacity for fashioning an alternative humanity through the work one does. In reflection on her experience she speaks of her 'existence [and] preoccupations with the inner life of the Self, and with the struggle of that Self amidst adversity and violation' (p. 3). She writes, 'I had to leave home so I could find myself, find my own intrinsic nature buried under the personality that was imposed on me' (p. 16).

In describing the mestiza, Anzaldúa contends that '[s]he has a plural personality, she operates in a pluralistic mode - nothing is thrust out, the good, the bad and the ugly, nothing rejected, nothing abandoned. Not only does she sustain contradictions, she turns the ambivalence into something else' (1987: 
79), drawing energy from this state to write from a deep place. These insights marked a turning point for me as a researcher and thinker since it allows me to occupy the borderlands, and to act in this pluralistic, dissonant space, enabling curriculum theorisation from the epistemic border. As Mignolo (2011) asserts, it is about thinking and learning from where we are especially given that we cannot escape or imagine a space outside of the colonial matrix of power since it is all encompassing. This is a comforting reassurance from powerful scholars since it allows me to help my students understand the borderlands that they occupy with the view to using that positionality as a resource for navigating the world. It enables me to appropriate ideas from the work of a range of critical scholars knowing that they may well depart from different ontological and epistemological premises, as is the case with my recent attempts at invoking posthumanism's theoretical tenets. Forlano cautions though, that 'it is not productive to speak of the posthuman when so many people - non-white, less privileged/powerful, female, older, indigenous, people with disabilities, and so on - have not been historically included in the category of the human in the first place' (2017: 29).

Decolonial Critique arose from the seminal work of Anibal Quijano in his theorisation of the hegemonic model of global power. The coloniality of power is a useful entry point into a discussion, especially with students in my programme, of how the contemporary capitalist world order has come to be. International capitalist western-euro-centred capitalism hinges on two axes modernity and the coloniality of power (Quijano 2000). Coercive physical (military) domination was sustainable (up to a point) for the coloniser. Coercive domination transcended into domination based on human epidemiology, together with the European coloniser's perception of the colonised indigenous peoples' lack of a Christian religious god. Having a spiritual belief system that was not Christian relegated the colonised native to that of lesser than human status, of animal, of slave. This marked the advent of the first forms of racialisation and human hierarchisation (Grosfoguel 2013). European colonisers thus fabricated a racial hierarchy and superiority that permeated every sphere of economic and social life for centuries. These insights help students historicise the contemporary.

Internationalised capitalism pivots on its other crucial axis modernity. The effect of modernity was to compound and reify the marginalisation of indigenous ways of thinking, knowing, and doing which led to systematic epistemicide. In Fanon's words, what colonialism did was to 


\section{S.M. Maistry}

empty 'the native's brain of all form and content. By a kind of perverse logic, it turns to the past of the oppressed people, and distorts it, disfigures and destroys it ... devaluing pre-colonial history' (1963: 261).

This nuanced understanding of how contemporary global socioeconomic inequality and racism has come to be, has certainly shaped my approach to my pedagogy and curriculum transformation endeavour. From an Economics perspective, it is important to recognise that colonialism ushered in a system of land ownership (coloniser ownership in the first instance). The notion of ownership of what was once unmarked, an undivided expanse into nation states and provinces, and individual land ownership marked the beginning of ascribing economic value to natural resources. It fuelled the belief that what I own is what I can choose to ruin or save. So the sense that the earth belongs to us (humans) exclusively, and the notion that even the wildlife belongs to governments, calls for a radical way of unthinking/unlearning and of seeing the human as co-agent in the ecological mix, respectful of non-human counterparts and appreciative of co-existence.

Decolonial Critique is certainly complexly layered. Both Anzaldua (987) and Lugones (2007) remind us of the precariousness of woman beings and how normative constructions of gender are implicated in the colonial matrix of power. These insights add a richness to curriculum transformation initiatives, well beyond technical tinkering.

\section{A Posthuman Tease/ Provocation}

Like Ulmer (2017), I experienced much discomfort with my engagement with posthumanist theory since I felt that I was shifting allegiance and betraying the critical project on which I was raised as activist student, teacher, and teacher educator. Having been fed on a diet of Critical scholarship and decolonial scholarship in recent years since decolonial debates started to (re)emerge in South Africa, I drew insights from Zembylas (2018) in an attempt to tease out moments of divergence and convergence of decolonial critique and posthumanism. He notes, though, that the commensurability of decolonial critique with posthumanism remains a fraught argument.

Posthumanism calls for a decentring of the human as the primary focus of research (Ulmer 2017). What distinguishes posthumanism as a theoretical heuristic for curriculum theorising is its planetary/global appeal, unlike Decolonial Critique and its appeal to previously colonised subjects wanting to 
shake off lingering coloniality. The crisis that COVID-19 currently presents for the world is a stark revelation of the fragility of humankind on the planet. It brings into sharp focus humankind's susceptibility to attack from non-human micro-organisms. Importantly, it has drawn attention to modernity's preoccupation with humankind as the paramount species whose needs, wants, and longevity has been at the expense of the non-human matter in the ecosphere. Posthumanism invokes a thinking that moves beyond the preoccupation with modern humans' material pursuits. It appeals to a planetary justice, a justice accruable to more than just the human; it necessarily includes everything that is non-human (Ulmer 2017). Egyptian-born American literary theorist, Ihab Hassan (1977) is credited with first introducing the concept of posthumanism. The concept has since morphed and assumed lines of flight in applications across an ever-growing spectrum of intellectual endeavours and has particular appeal for curriculum and pedagogy studies.

Posthumanism's multiplicity of characteristics and features (Ulmer 2017) make it an elusive field to capture in definitive terms. It does have as its central tenet, though, the object of decentring the human as the focal point of our intellectual endeavours. It takes issue with contemporary conceptions of humans that derive from modernity's fixation with a science of things that have, to date, rendered an epoch characterised by modern humans' indelible, destructive footprint in every realm of the geosphere. The Anthropocene marks an era of human existence in which the supremacy and prioritisation of the human (and human need satisfaction) at the expense of other living and nonliving matter. It is an epoch that has unequivocally demonstrated the negative geological impact that humans have had and continue to have on the planet (Crutzen 2002).

In engaging with curriculum transformation initiatives, it becomes imperative for a deliberative praxical orientation that is unapologetically political. For teachers working in the field of Economics and Business Science, there is need for an understanding of the profound imbrication of the complicity of modernity and neoliberal capitalism in perpetuating economic exploitation of the natural world (including that of humans). Forlano's (2017: 27) sceptical caution is important since she reminds us that celebratory posthumanism is premised on 'an understanding of the human based on the notion of a universal subject - usually white, male, privileged, well-off, and young - that does not exist in reality'. The COVID-19 pandemic has been particularly powerful in drawing attention to the dangers of conceptualising a 


\section{S.M. Maistry}

universal subject and it has become strikingly clear that the virus does not discriminate with regard to its potential host. Historically entrenched socioeconomic inequalities, though, render certain segments of society, including the indigent who are most prone to having underlying health conditions, and women in captive contexts, susceptible to serious infection and increased chances of fatality.

\section{About Transitioning and Cognitive Dissonance}

The elucidation above, presented as linear occurrence with somewhat neat transitions might be misleading. If anything, paradigmatic transitions are intensely complex and traumatic for the subject (myself) who is likely to experience feelings of anxiety, uncertainty, and loss of self-belief. As researcher and scholar, I am learning what it means to exist in a space of perennial cognitive dissonance, characterised by (self) contradiction, wild leaps of faith to pursue research, and scholarship that unsettles (me). Inhabiting and operating at the proverbial border forces me to develop proclivities for constantly unlearning and learning anew.

\section{Concluding Comments}

In this paper, I attempted an exposition of what has informed my approach to curriculum theorising as it relates to the teacher education pedagogy courses I design and teach. I drew on the tenets of self-study research to problematize (my)self as key architect in the design and construction of my programme. I reflect on personal trauma of being born into a pre-configured world, a world view which remains circumscribed by the colonial matrix of power. I engaged the notion of the metaphorical border as powerful space to inhabit and act as I engage my students with understanding their own border occupancy. I offered a brief account of the difference in ontological premises that Decolonial Critique and Posthumanism depart with a view to understanding how these theoretical heuristics magnify different phenomena for scrutiny, transformation, and theorisation. It has however become increasingly apparent that conventional educational research methodology (and subsequent curriculum theorising) is under contestation given the radical turn that posthumanism has presented (Ulmer 2017). 


\section{References}

Anzaldúa, G.E. 1987. Borderlands/ La Frontera: The New Mestiza. San Francisco: Aunt Lute Book Company.

Arendt, A. 1973. The Origins of Totalitarianism. New York: Harcourt Brace Jovanovich.

Arendt, H. 1998. The Human Condition. Chicago: University of Chicago Press. Bauman, Z. 2007. Liquid Times: Living in a World of Uncertainty. Cambridge: Polity Press.

Bauman, Z. \& C. Rovirosa-Madrazo. 2010. Living on Borrowed Time. Cambridge: Polity Press.

Burrell, S.R. \& M. Flood. 2019. Which Feminism? Dilemmas in Profeminist Men's Praxis to End Violence against Women. Global Social Welfare 6: 231-244. https://doi.org/10.1007/s40609-018-00136-X

Butler, J. 1990. Gender Trouble: Feminism and the Subversion of Identity. London: Routledge.

Butler, J. 2004. Undoing Gender. London: Routledge.

https://doi.org/10.4324/9780203499627

Cervantes-Soon, C.G. \& J.F. Carillo. 2016. Toward a Pedagogy of Border

Thinking: Building on Latina Students' Subaltern Knowledge. The High School Journal 99, 4: 282-301. https://doi.org/10.1353/hsj.2016.0016

Craig, C J. 2009. Trustworthiness in Self-Study Research. In Lassonde, C., S. Galman \& C. Kosnick (eds.): Self-Study Research Methodologies for Teacher Educators. London: Sense Publishers.

Crutzen, Paul J. 2002. Geology of Mankind. Nature 415, 6867: 23-43. https://doi.org/10.1038/415023a; PMid:11780095

De Jager, P.L., G. Reeler, M.O. Oberholzer \& W.A. Landman 1985. Fundamental Pedagogics: Science, Content and Practice. Halfway House: NG Kerkboekhandel.

Deleuze, G. \& F. Guattari. 1987. A Thousand Plateaus. Minneapolis: University of Minnesota Press.

Fairclough, N. 2003. Analysing Discourse: Textual Analysis for Social Research. London: Routledge. https://doi.org/10.4324/9780203697078

Fanon, F. 1963. The Wretched of the Earth. Farrington, C. (trans.). New York: Grove Press, Inc.

Fanon, F. 1967. Black Skins, White Masks.. Markmann, C. (trans.). London: Pluto Press. 
Feldman, A. 2009. Making the Self Problematic: Data Analysis and Interpretation in Self-study Research. In Lassonde, C., S. Galman \& C. Kosnick. Self-study Research Methodologies for Teacher Educators. Rotterdam: Sense Publishers.

Forlano, L. 2017. Posthumanism and Design. Journal of Design, Economics and Inovation 3, 1:16-30.

https://doi.org/10.1016/j.sheji.2017.08.001

Foucault, M. 1979. Discipline and Punish: Birth of Prisons. S.S. A.M. (trans.). New York: Vintage.

Foucault, M. 2001. Fearless Speech. Pearson, J. (ed.). New York: Semiotext(e).

Freire, P. 1970. Pedagogy of the Oppressed. Ramos, M.B. (trans.). London: The Continuum Publishing Company.

Friedman, B.M. 2010. Reconstructing Economics in Light of the 2007-?

Financial Crisis. The Journal of Economic Education 41, 4: 391-397.

https://doi.org/10.1080/00220485.2010.510397

Giroux, H.A. 2004. Critical Pedagogy and the Postmodern/ Modern Divide:

Towards a Pedagogy of Democratization. Teacher Education Quarterly 31, 1: 31-47.

Gray, R. \& B. Maharaj 2016. Poverty, Inequality and Violence: A Case Study of Cato Manor. People, Places and Infrastructure: Countering Urban Violence and Promoting Justice in Mumbai, Rio, and Durban. Mumbai, Rio De Janeiro, Surban: Tata Institute of Social Sciences, Universidade Federal Do Rio De Janaeiro, University of Kwazulu-Natal, International Development Research Centre.

Grosfoguel, R. 2007. The Epistemic Decolonial Turn: Beyond Political

Economy Paradigm. Cultural Studies 21, 3: 203-246.

https://doi.org/10.1080/09502380601162514

Grosfoguel, R. 2008. Latinos and the Decolonisation of America in the $21^{\text {st }}$ Century. Social Science Information 47, 4: 605-652.

https://doi.org/10.1177/0539018408096449

Grosfoguel, R. 2011. Decolonizing Post-Colonial Studies and Paradigms of Political-Economy: Transmodernity, Decolonial Thinking, and Global

Coloniality. Transmodernity: Journal of Peripheral Cultural Production of the Luso-Hispanic World 1, 1: 2-38.

Grosfoguel, R. 2013. The Structure of Knowledge in Westernized Universities:

Epistemic Racism/ Sexism and the Four Genocides/ Epistemicides of the 
Long $16^{\text {th }}$ Century. Human Architecture: Journal of the Sociology of SelfKnowledge 11, 1: 73-90.

Harvey, D. 2007. A Brief History of Neoliberalism. Oxford: Oxford University Press.

Harvey, D. 2010. The Enigma of Capital. London: Profile Books Limited.

Hassan, I. 1977. Prometheus as Performer: Towards a Posthumanist Culture.

The Georgia Review 31, 4: 830-850.

hooks, b. 1994. Teaching to Transgress: Education as the Practice of Freedom. New York: Routledge.

Hoyt, G.M. \& K. McGoldrick. 2019. 50 Years of Economic Education in The Journal of Economic Education. The Journal of Economic Education 50, 2:168-195.

https://doi.org/10.1080/00220485.2019.1582388

Jansen, J. 1997. Essential Alterations? A Critical Analysis of the State's Syllabus Revision Process. Perspectives in Education 17: 1-11.

Jansen, J. 1998. Curriculum Reform in South Africa: A Critical Analysis of Outcomes-Based Education. Cambridge Journal of Education 28, 3: 221332.

https://doi.org/10.1080/0305764980280305

Lugones, M. 2007. Heterosexualism and the Colonial/ Modern Gender System. Hypatia 22, 1:186-209. https://doi.org/10.1353/hyp.2006.0067

Madsen, P.T. 2013. The Financial Crisis and Principles of Economics Textbooks The Journal of Economic Education 44, 3: 197-216. https://doi.org/10.1080/00220485.2013.795450

Maistry, S.M. 2011. Transformation through the Curriculum: Engaging a Process of Unlearning in Economics Education Pedagogy. Alternation 18, 2:115-134.

Maistry, S.M. 2012a. Foregrounding a Social Justice Agenda in Economic Education: Critical Reflections of a Teacher Education Pedagogue. Journal for New Generation Sciences 10, 2: 30-45.

Maistry, S.M. 2012b. Using Memory as a Resource for Pedagogy: Fashioning a 'Bridging Pedagogical Moment'. Journal of Education 54: 65-84).

Maistry, S.M. 2014. Education for Economic Growth: A Neoliberal Fallacy! Alternation 21,1: 57-75.

Maistry, S.M. 2015. An Analysis of Economic Modelling used in School Economics Textbooks. In Hugo, W. (ed.): Picking up Knowledge: Conceptual Integration and Educational Analysis. Pretoria: HSRC Press. 
Maistry, S M. 2019. Fetishistic Disavowal and Elusive Jouissance: The Case of the South African Higher Education Decolonization Project. South African Journal of Higher Education 33, 4: 171-185.

https://doi.org/10.20853/33-4-3146

Maistry, S.M. 2019. The Higher Education Decolonisation Project: Negotiating Cognitive Dissonance. Transformation: Critical Perspectives on Southern Africa 100: 179-189.

https://doi.org/10.1353/trn.2019.0027

Maistry, S.M. \& R. David. 2017. Phantasmagoria: Communicating an Illusion of Entrepreneurship in South African School Textbooks. Educational Research for Social Change 6, 2:101-114. https://doi.org/10.17159/2221-4070/2017/v6i2a7

Maistry, S. M. \& R. David. 2018. The School Economics Textbook as Programmatic Curriculum: An Exploited Conduit for Neoliberal Globalisation Discourses. Journal of Education 74: 32-46.

https://doi.org/10.17159/2520-9868/i74a03

Maldanado-Torres, N. 2007. On the Coloniality of Being. Cultural Studies 21, 2/3: 240-270.

https://doi.org/10.1080/09502380601162548

McLaren, P. 2005. Critical Pedagogy and Class Struggle in the Era of Neoliberal Globalisation: Notes from History's Underside. The International Journal of Inclusive Democracy 2, 1: 1-24.

Mignolo, W. 2002. The Geopolitics of Knowledge and Colonial Difference.

South Atlantic Quarterly 101, 1: 56-96.

https://doi.org/10.1215/00382876-101-1-57

Mignolo, W. 2009. Epistemic Disobedience, Independent Thought and Decolonial Freedom. Theory, Culture and Society 26, 7/8: 1-23. https://doi.org/10.1177/0263276409349275

Mignolo, W. 2011. Epistemic Disobedience and the Declonial Option: A Manifesto. Transmodernity Fall, 44-66.

Nussbaum, M. 2003. Capabilities as Fundamental Entitlements: Sen and Social Justice. Feminist Economics 9, 2: 33-59.

https://doi.org/10.1080/1354570022000077926

Nussbaum, M.C. 2006. Frontiers of Justice. London: Belknap Press.

Nussbaum, M.C. 2010. Not for Profit: Why Democracy Needs the Social Sciences. New Jersey: Princeton University Press.

Petkus, M., J. Perry \& K.B. Johnson. 2014. Core Requirements for the 
Economics Major. The Journal of Economic Education 45, 1: 56-62. https://doi.org/10.1080/00220485.2014.859961

Picketty, T. 2014. Capital in the Twenty-First Century. London: Cambridge

University Press. https://doi.org/10.4159/9780674369542

Pillay, P. \& S.M. Maistry. 2018. The 'Firstness' of Male as Automatic Ordering: Gendered Discourse in Southern African Business Studies School Textbooks. Journal for Transdisciplinary Research in Southern Africa 14, 2: 1-19. https://doi.org/10.4102/td.v14i2.484

Pogge, T. 2010. Politics as Usual: What Lies behind the Pro-Poor Rhetoric. Cambridge: Polity Press.

Quijano, A. 2000. Coloniality of Power, Eurocentrcism and Latin America. Nepantla: Views from the South 1.3: 533-580.

Raghuram, R. 2010. The Financial Crisis and the Death (or Hegemony) of Development Economics. The Journal of Economic Education 41, 4: 398-402. https://doi.org/10.1080/00220485.2010.510398

Samaras, A.P. \& A.R.Freese. 2009. Looking Back and Looking Forward: An Historical Overview of the Self-Study School. In Lassonde, C., S. Galman \& C. Kosnick (eds.): Self-Study Research Methodologies for Teacher Educators. London: Sense Publishers.

Samaras, A.P. 2011. Self-Study Teach Research: Improving your Practice through Collaborative Inquiry. London: SAGE.

Sen, A. 2009. The Idea of Justice. London: Allen Lane.

https://doi.org/10.2307/j.ctvjnrv7n

Sen, A. 2005. Human Rights and Capabilities. Journal of Human Development 6, 2: 151-166. https://doi.org/10.1080/14649880500120491

Shiller, R.J. 2010. How Should the Financial Crisis Change How We Teach Economics? The Journal of Economic Education 41, 4: 403-409. https://doi.org/10.1080/00220485.2010.510409

Shulman, L.S. 2005. Signature Pedagogies in the Professions. Daedalus 134, 3: 52-59. https://doi.org/10.1162/0011526054622015

Suransky-Dekker, C. 1998. A Liberating Breeze of Western Civilisation: A Political History of Fundamental Pedagogics as an Expression of DutchAfrikaaner Relationships. Full Curriculum Studies, University of DurbanWestville, Durban.

Ulmer, J.B. 2017. Posthumanism as Research Methodology: Inquiry in the Anthropocene. International Journal of Qualititative Studies in Education, 30, 9: 832-848. 
https://doi.org/10.1080/09518398.2017.1336806

Van Dijk, T.A. 2006. Ideology and Discourse Analysis. Journal of Political Ideologies 11, 2:115-140. https://doi.org/10.1080/13569310600687908

Wodak, R. 2005. Understanding and Explaining Social Change: Deja vu Experiences. International Journal of Applied Linguistics 15, 2: 240-243. https://doi.org/10.1111/j.1473-4192.2005.00089.x

Wodak, R. \& M. Meyer. 2009. Critical Discourse Analysis: History, Agenda, Theory and Methodology. In Wodak, R. \& M. Meyer (eds.): Methods of Critical Discourse Analysis. London: Sage.

Yosso, T.J. 2005. Whose Culture has Capital? A Critical Race Theory Discussion of Community Cultural Capital. Race, Ethnicity and Education 8, 1: 69-91. https://doi.org/10.1080/1361332052000341006

Zembylas, M. 2018. The Entanglement of Decolonial and Posthuman Perspectives: Tensions and Implications for Curriculum and Pedagogy in Higher Education. Parallax 24. 3: 254-267.

https://doi.org/10.1080/13534645.2018.1496577

S.M. Maistry

Professor

Social Sciences Education University of KwaZulu-Natal Durban maistrys@ukzn.ac.za 